\title{
PEMBELAJARAN LUAS SEGIEMPAT UNTUK SISWA KELAS VII MENGGUNAKAN REALLOTMENT ACTIVITIES
}

\author{
Nur Lailatul Fitri, Rully Charitas Indra Prahmana \\ Pendidikan Matematika FKIP Universitas Ahmad Dahlan Yogyakarta
}

\begin{abstract}
This research uses reallotment activities that already designed by previous research to know the role of reallotment activities in great rectangular learning. This research uses descriptive research method implemented in class 7 th at SMPN 3 Banguntapan, Bantul, Yogyakarta. The data collection techniques used are documentation, observation, and test. Furthermore, the researcher analyzed the data obtained through video recording, observation, and student test answers. The results show that reallotment activities can assist students in finding the square formula by changing the shape of a rectangle into a rectangular shape. The learning activities that use reallotment activities consist of action comparing the area of an irregular shape, replacing the regular form into squares, determining the area of the rectangle and the parallelogram, finding the formula of the breadth of the parallelogram, and also determining the area of the trapezium, the parallelogram, and kite.
\end{abstract}

Keywords: Reallotment activities; Square; Realistic Mathematics Education

\section{PENDAHULUAN}

Geometri sudah dikenal oleh siswa sebelum masuk sekolah formal sehingga berpeluang besar untuk dipahami oleh siswa dan menjadi salah satu subjek penting dalam pembelajaran matematika (Khotimah, 2013; Rofii, Sunardi, \& Irvan, 2018). Hal ini didukung oleh Kolnel, Prahmana, dan Arifin (2015) yang menyatakan bahwa geometri memiliki peluang yang lebih besar untuk dipahami siswa dibandingkan cabang matematika lainnya karena siswa telah mengenal banyak benda-benda yang berkaitan dengan geometri dalam kehidupan sehari-hari. Mereka memiliki banyak pengalaman untuk mempelajari geometri ke arah yang lebih kompleks berdasarkan pengalaman mereka melihat bentuk geometri dalam kehidupan sehari-hari (Khoiri, 2014; Muhtadi, dkk. 2017; Novita, dkk. 2018). Namun, hasil observasi di lapangan menunjukkan bahwa siswa masih melakukan kesalahan dalam menyelesaikan permasalahan geometri dalam proses pembelajaran matematika.

Sejumlah peneliti melakukan analisis kesalahan-kesalahan siswa dalam pembelajaran geometri khususnya bangun datar (Kurniati, 2010; Darmawati, Irawan, \& Chandra, 2017; Ismail \& Rahman, 2017). Kurniati (2010) menyatakan bahwa kesalahan 
siswa dalam menyelesaikan soal luas dan keliling dari persegi dan persegi panjang terletak pada kesalahan konsep, prinsip, operasi dan kesalahan lainnya. Salah satunya disebabkan siswa suka lupa rumus untuk menghitung luas dan keliling bangun datar. Beberapa kesalahan lain yang dilakukan siswa dalam menyelesaikan soal bangun datar segiempat yaitu careless errors, concept errors, application errors, dan test taking errors (Darmawati, Irawan, \& Chandra, 2017). Berdasarkan beberapa hasil penelitian tersebut menunjukkan bahwa kesalahan terbesar terletak pada tataran konsep, sehingga siswa diharapkan mampu menguasai konsep bangun datar.

Salah satu pendekatan yang dapat digunakan untuk meningkatkan pemahaman konsep matematika pada siswa adalah pendekatan Pendidikan Matematika Realistik Indonesia (PMRI) (Revina \& Leung, 2018; Nugraheni \& Sugiman, 2013; Ryandi, Somakim, \& Susanti, 2018). PMRI diadaptasi dari teori RME (Realistic Mathematics Education) yang dikembangkan oleh Hans Freudenthal di Belanda yang menggunakan objek yang dekat dengan siswa sebagai titik awal pembelajaran matematika (Prahmana, 2012; Prahmana, Zulkardi, \& Hartono, 2012). Pendekatan PMRI memberikan kesempatan kepada siswa untuk menemukan sendiri konsep matematika di bawah bimbingan guru menggunakan konteks kehidupan sehari-hari yang dekat dengan siswa (Olivia, Deniyati, \& Meiliasari, 2013; Mumu, Prahmana, \& Tanujaya, 2017). Oleh karena itu, pendekatan PMRI dianggap mampu membantu siswa untuk meningkatkan pemahaman konsep matematika menggunakan berbagai hal yang dekat dengan siswa, salah satunya konsep geometri yang sering ditemui siswa dalam keseharian mereka.

Yunianto (2014) telah membuat desain pembelajaran luas segiempat dan segitiga menggunakan pendekatan PMRI, yang menghasilkan tahapan pembelajaran luas segiempat dan segitiga menggunakan reallotment activities. Inovasi ini mendasari peneliti untuk mempelajari lebih jauh terkait reallotment activities, dikarenakan aktivitas ini memiliki tahapan pembelajaran yang mampu membimbing siswa untuk memahami konsep bangun datar dengan baik. Oleh karena itu, digunakan desain pembelajaran yang telah dihasilkan (reallotment activities) pada pembelajaran luas bangun datar khususnya segiempat di SMP Negeri 3 Banguntapan dan mendeskripsikan proses pembelajarannya, sehingga dapat diketahui peran reallotment activities dalam menanamkan konsep segiempat pada pembelajaran luas segiempat. 


\section{METODE PENELITIAN}

Penelitian ini merupakan jenis penelitian deskriptif yang mendeskripsikan proses pembelajaran luar segiempat menggunakan reallotment activities. Prosedur penelitian ini meliputi tahap persiapan, tahap pelaksanaan, dan analisis data (Prahmana, 2015). Penelitian dilakukan di SMP Negeri 3 Banguntapan pada semester genap tahun ajaran 2017/2018. Subjek penelitian adalah siswa kelas VIIG yang terdiri dari 32 siswa. Teknik pengumpulan data yang digunakan berupa dokumentasi (foto dan video), observasi, dan tes tertulis. Data foto, video, dan hasil observasi yang diperoleh dari hasil dokumentasi dan observasi dianalisis menggunakan teknik triangulasi data untuk menggambarkan serta mendeskripsikan proses pembelajaran, sehingga dapat melihat peran dari aktivitas yang diberikan. Selanjutnya, hasil tes tertulis disajikan secara deskriptif untuk melihat perubahan nilai sebelum dan setelah diberikan perlakukan, sehingga dapat diketahui peningkatan nilai siswa.

\section{HASIL DAN PEMBAHASAN}

Penelitian ini terbagi dalam beberapa aktivitas. Siswa bekerja secara berkelompok untuk menyelesaikan sejumlah aktivitas tersebut. Terdapat 8 kelompok yang dijadikan subjek penelitian dengan jumlah siswa tiap kelompok terdiri dari 4 orang siswa. Adapun penjelasan dari setiap aktivitas tersebut adalah sebagai berikut.

\section{Membandingkan luas bentuk tak beraturan}

Pada aktivitas pertama, siswa dihadapkan pada masalah kontekstual yaitu membandingkan dua buah daun. Tujuan dari aktivitas ini yaitu memberikan pemahaman kepada siswa bahwa bentuk tak beraturan memiliki luas yang dapat dibandingkan. Tujuan lain dari aktivitas ini yaitu menemukan strategi pengubahan bentuk dengan cara memotong dan menempel.

Salah satu kelompok, dalam hal ini kelompok 5, melakukan strategi menumpuk kedua buah daun lalu memotong sisa daun A. Potongan tersebut kemudian ditempelkan pada permukaan daun B. Mereka memberikan keterangan nama pada setiap daun. Hal tersebut memudahkan mereka dalam membedakan daun A dan daun B. Kelompok ini menyebutkan bahwa daun B memiliki sisa, seperti tampak pada Gambar 1. Sehingga, mereka menyimpulkan bahwa daun B lebih lebar dari daun A. 

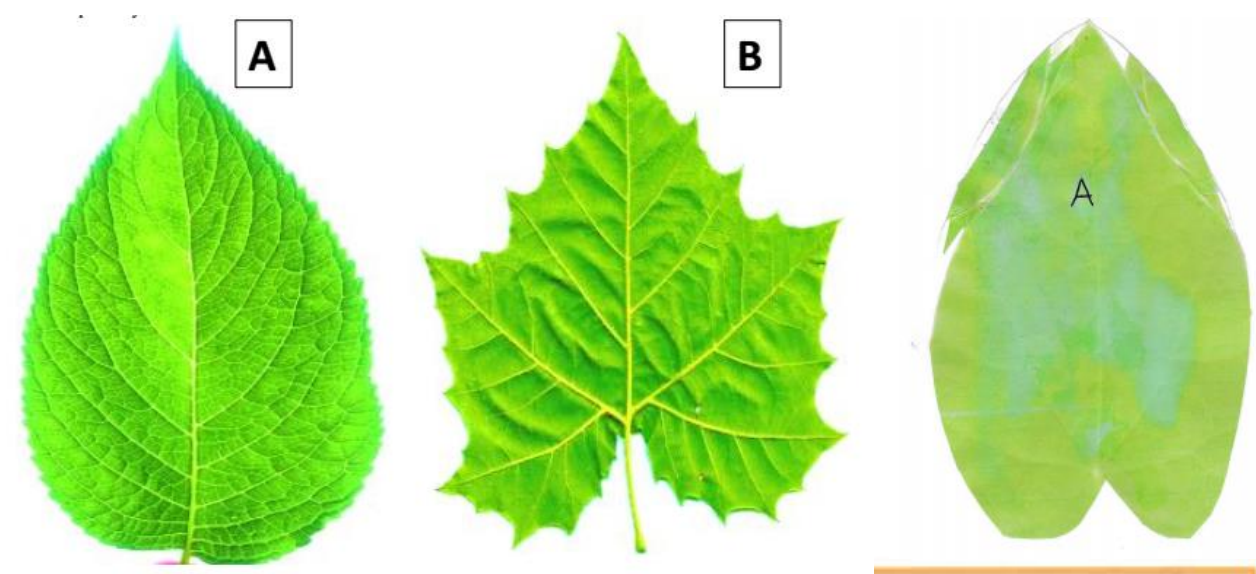

Tentukan daun mana yang akan memperoleh lebih banyak sinar matahari. Jelaskan bagaimana kalian menyelesaikan masalah tersebut.

$$
\begin{aligned}
& \text { Dawn B. beorena sezelah ledua daun itu dipotong lalu disamakan, } \\
& \text { daun B lebilh besar dari dawn A, karena terdapat sisa. }
\end{aligned}
$$

Gambar 1. Strategi Penyelesaian Masalah Kelompok 5

\section{Mengubah bentuk bangun datar beraturan menjadi persegi panjang}

Tujuan dari aktivitas kedua ini adalah siswa dapat mengubah bentuk beraturan menjadi persegi panjang. Tujuan lain dari aktivitas ini, siswa mengetahui bahwa strategi pengubahan bentuk (reallotment activities) tidak mengubah luas bentuk aslinya. Selain itu, siswa memahami konsep luas yaitu daerah yang berada di dalam sebuah batas.
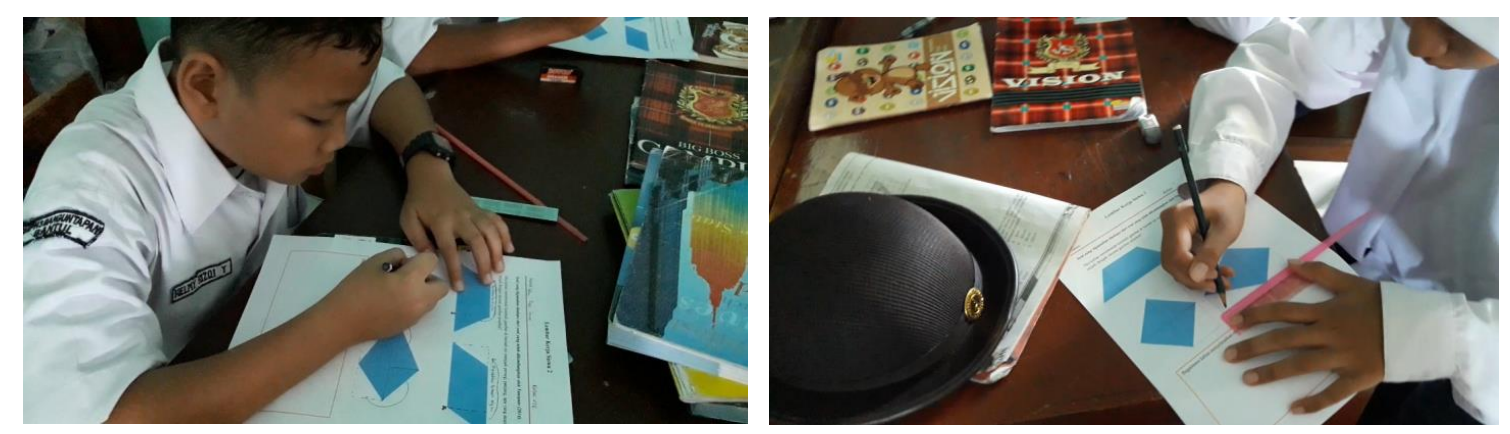

Gambar 2. Siswa Mengubah Bentuk Beraturan Menjadi Persegi Panjang

Siswa berusaha menggambar sebaik mungkin. Beberapa siswa yang tidak memiliki penggaris berusaha untuk meminjam temannya. Hal menarik dari kegiatan ini adalah ketika siswa tidak sabar menunggu temannya selesai menggunakan penggaris. Mereka kemudian memanfaatkan benda-benda yang mereka miliki seperti buku, hingga sisir untuk menggaris, seperti tampak pada Gambar 2.

Siswa menambahkan beberapa keterangan dalam gambar mereka. Keterangan tersebut berupa arsiran, huruf, tanda anak panah hingga gambar gunting. Hal tersebut 
mereka lakukan untuk mempermudah dalam menjelaskan strategi penyelesaian masalah yang mereka gunakan. Seperti yang dilakukan oleh salah seorang subjek penelitian bernama Helmy yang menambahkan keterangan angka, huruf anak panah dan juga gambar gunting, seperti tampak jelas terlihat pada Gambar 3. Gambar gunting mengartikan bahwa sebagian dari bentuk beraturan dipotong (misalnya: bagian a) lalu dipindahkan sesuai dengan anak panah. Kegiatan ini dapat menstimulasi siswa untuk mengubah berbagai bentuk bangun datar ke bentuk persegi panjang sebagai satu-satu nya bangun datar yang mereka kenal, ketahui, dan pahami di awal pembelajaran bangun datar.
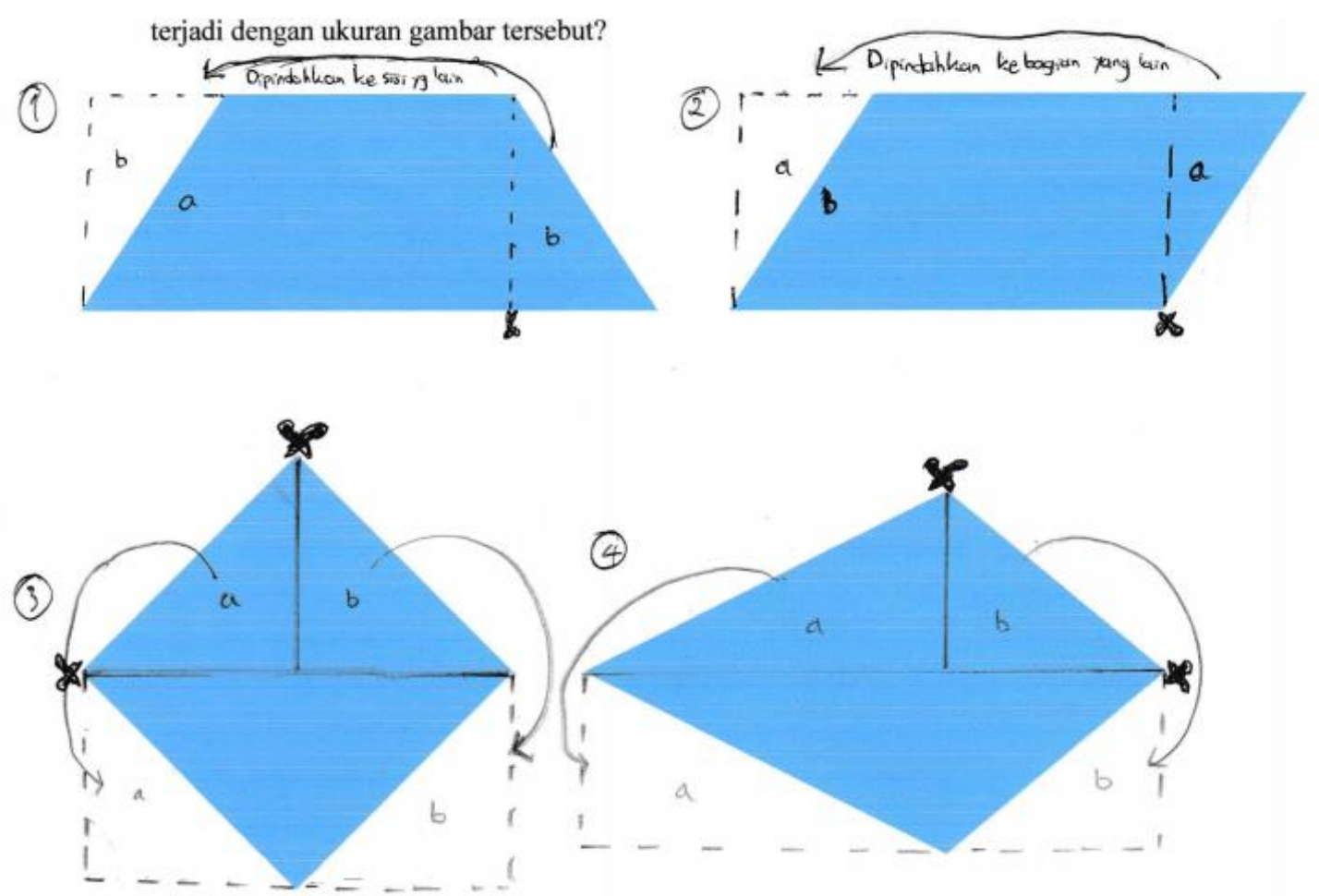

Gambar 3. Siswa Mengubah Bentuk Beraturan Menjadi Persegi Panjang

\section{Menentukan luas kaca pada bangunan berbentuk persegi panjang dan jajargenjang}

Pada aktivitas ketiga ini, siswa diminta untuk menentukan dan membandingkan luas kaca yang menutupi bangunan berbentuk persegi panjang dan jajargenjang jika dilihat dari salah satu sisi. Tujuan dari aktivitas ini yaitu, menentukan luas persegi panjang dan menemukan rumus luasnya. Selain itu, siswa dapat menentukan luas jajar genjang dengan mengubahnya menjadi bentuk persegi panjang. 

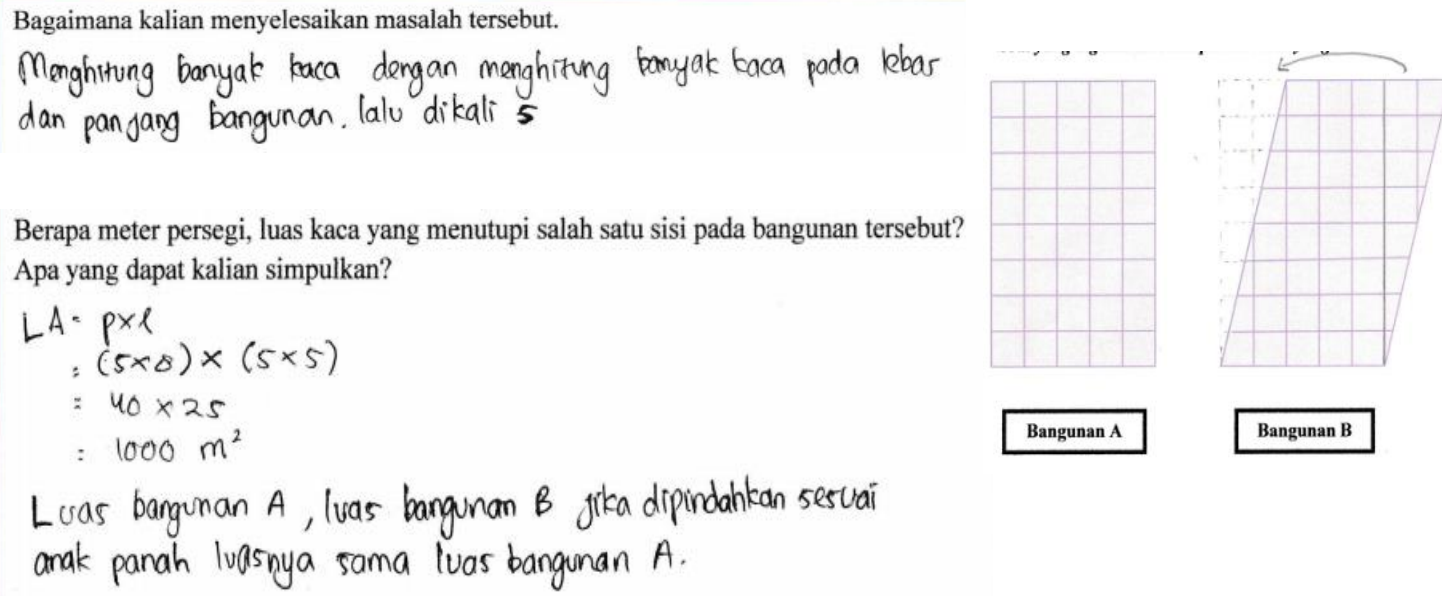

Gambar 4. Strategi Penyelesaian Masalah Kelompok 6

Kelompok 6 menggunakan strategi pengubahan bentuk untuk menghitung luas bangunan B. Mereka mengubah bentuk jajargenjang menjadi persegi panjang (Gambar 4). Mereka menyadari bahwa ukuran bangunan A dan B sama. Sehingga mereka hanya menuliskan satu perhitungan saja. Mereka menghitung luas kaca pada bangunan A dan bangunan B dengan mencari panjang dan lebar bangunan terlebih dahulu. Panjang bangunan terdiri dari 8 kotak, sedangkan lebarnya terdiri dari 5 kotak. Setiap kotak memiliki panjang $5 \mathrm{~m}$. Sehingga diperoleh bahwa panjang dan lebar bangunan A berturut-turut adalah $40 \mathrm{~m}$ dan $25 \mathrm{~m}$. Mereka kemudian mengalikan panjang dengan lebarnya. Jadi, luas kaca yang menutupi salah satu sisi pada bangunan tersebut yaitu $1000 \mathrm{~m}^{2}$.

\section{Menentukan luas jajargenjang}

Tujuan dari aktivitas ini adalah siswa dapat menentukan luas jajar genjang beserta rumus umum untuk mencari luas jajar genjang. Kelompok 1 mengubah bentuk jajar genjang menjadi persegi panjang. Mereka kemudian mencari tahu hubungan antara jajar genjang dan persegi panjang. Panjang pada persegi panjang merupakan tinggi dari jajar genjang. Sedangkan lebarnya merupakan alas dari jajar genjang. Sehingga mereka menuliskan $p \times l=t \times a($ Gambar 5). 

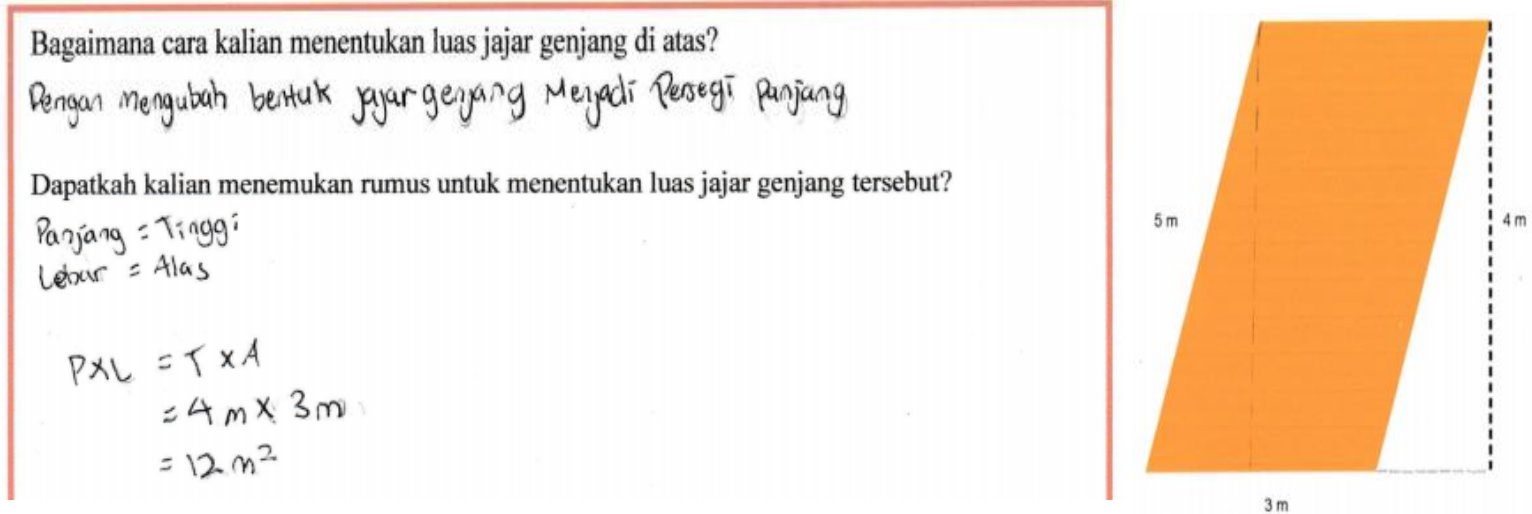

Gambar 5. Strategi Penyelesaian Masalah Kelompok 1

\section{Menentukan luas kaca pada bangunan berbentuk trapesium}

Pada aktivitas kelima, siswa diminta untuk menentukan luas kaca yang menutupi salah satu sisi pada bangunan. Tujuan dari aktivitas ini yaitu, menentukan luas trapesium. Selain itu, mengubah trapesium menjadi bentuk persegi panjang.

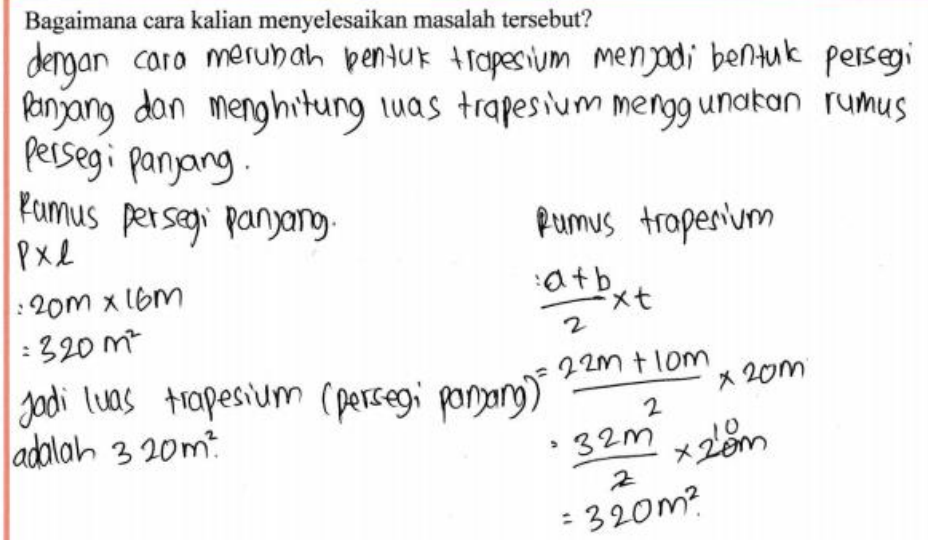

$$
\begin{aligned}
& =\frac{32 \mathrm{~m}^{2}}{2} \times 20 \mathrm{~m} \\
& =320 \mathrm{~m}^{2} .
\end{aligned}
$$

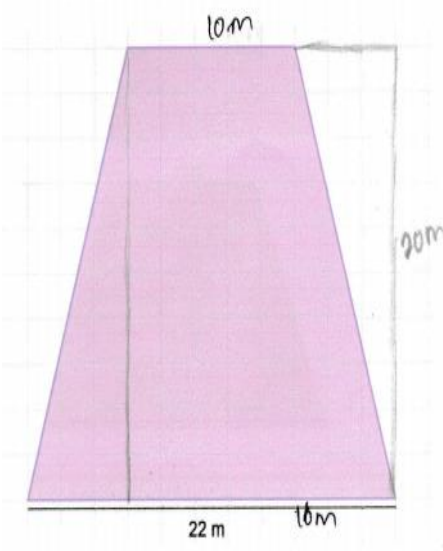

Gambar 6. Strategi Penyelesaian Masalah Kelompok 3

Kelompok 3 menggunakan dua cara dalam menentukan luas kaca. Cara pertama dilakukan mengubah trapesium menjadi bentuk persegi panjang. Mereka kemudian menggunakan rumus luas persegi panjang untuk menghitung luasnya. Dengan mengalikan panjang dan lebar yaitu $20 \mathrm{~m}$ dan $16 \mathrm{~m}$ diperoleh luas kaca $320 \mathrm{~m}^{2}$. Cara kedua dilakukan menggunakan rumus trapesium (Gambar 6). Meskipun rumus yang digunakan berbeda, namun hasil yang diperoleh sama yaitu $320 \mathrm{~m}^{2}$.

\section{Menentukan luas belah ketupat dan layang-layang}

Tujuan dari aktivitas keenam ini yaitu menentukan luas belah ketupat dan layanglayang. Selain itu, menemukan rumus luas belah ketupat dan layang-layang dengan mengubahnya menjadi bentuk persegi panjang. 

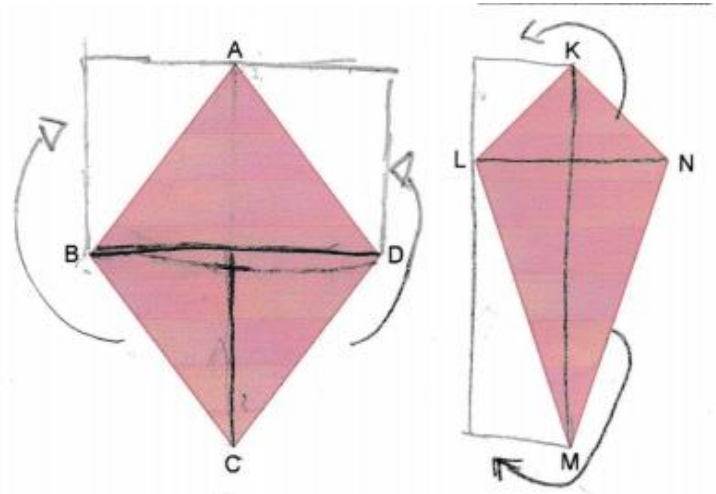

Gambar 7. Strategi Pengubahan Bentuk Kelompok 7

Setelah mengubah bentuk belah ketupat dan layang-layang menjadi persegi panjang, kelompok 7 kemudian menghitung luas keduanya menggunakan rumus luas persegi panjang. Dengan mengubah belah ketupat menjadi persegi panjang (Gambar 7), mereka tahu bahwa panjang pada persegi panjang sama dengan panjang diagonal BD, sedangkan lebarnya sama dengan setengah dari panjang diagonal AC. Begitu pula ketika mereka mengubah layang-layang menjadi persegi panjang, mereka tahu bahwa panjang pada persegi panjang sama dengan panjang diagonal KM, sedangkan lebarnya sama dengan setengah dari panjang diagonal LN. Berdasarkan perhitungan mereka menggunakan rumus luas persegi panjang, diperoleh luas belah ketupat dan layanglayang berturut-turut adalah $24 \mathrm{~cm}^{2}$ dan $16 \mathrm{~cm}^{2}$.

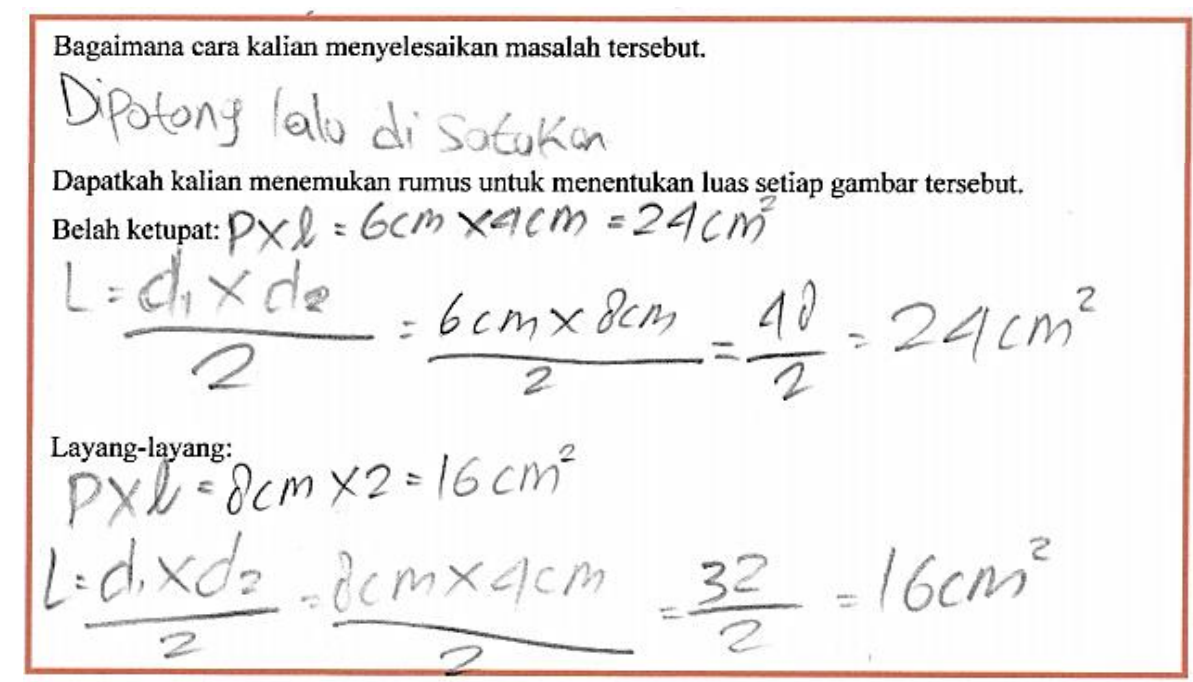

Gambar 8. Strategi Penyelesaian Masalah Kelompok 1

Strategi pengubahan bentuk yang telah mereka lakukan dapat membantu mereka dalam menemukan rumus luas belah ketupat dan layang-layang yaitu $\frac{d_{1} \times d_{2}}{2}$. Mereka kemudian menggunakan rumus tersebut untuk menghitung luas. Diperoleh luas belah 
ketupat dan layang-layang berturut-turut adalah $24 \mathrm{~cm}^{2}$ dan $16 \mathrm{~cm}^{2}$. Baik menggunakan rumus luas persegi panjang maupun rumus luas belah ketupat dan layang-layang, keduanya memberikan hasil yang sama yaitu $24 \mathrm{~cm}^{2}$ untuk luas belah ketupat dan $16 \mathrm{~cm}^{2}$ untuk luas layang-layang (Gambar 8).

Hasil yang diperoleh dalam penelitian ini menunjukkan bahwa kegiatan pembelajaran mampu membimbing siswa menguasai konsep segiempat. Strategi tidak mengubah luas bentuk aslinya reallotment activities pada proses pembelajaran menunjukkan kemampuan reversibilitas siswa sehingga mampu menguasai konsep tersebut. Hal ini relevan dengan hasil penelitian Balingga, Prahmana, dan Murniati (2016) terkait analisis kemampuan reversibilitas siswa MTs. Selain itu, hasil penelitian ini menambah bukti empiris yang menyatakan bahwa aktivitas yang dekat dengan siswa sangat berperan dalam penguasaan konsep pembelajaran matematika sebagaimana telah diteliti oleh sejumlah peneliti sebelumnya (Prahmana, 2012; Yunianto, 2014; Muhtadi, dkk. 2017; Nugraheni \& Sugiman, 2013; Olivia, Pinta, \& Meiliasari, 2013; Prahmana, Zulkardi, \& Hartono, 2012; Revina \& Leung, 2018; Ryandi, Somakim, \& Susanti, 2018).

\section{SIMPULAN DAN SARAN}

Strategi pengubahan bentuk (reallotment activities) dapat membantu siswa dalam memahami konsep luas. Strategi tersebut tidak mengubah luas bentuk aslinya. Dengan kata lain, reallotment activities dapat mempertahankan luas suatu bentuk meskipun bentuknya telah diubah. Selain itu, reallotment activities dapat membantu siswa dalam menemukan rumus luas segiempat dengan mengubah bentuk segiempat menjadi bentuk persegi panjang. Peneliti selanjutnya dapat melakukan penelitian eksperimen dengan membandingkan 2 kelas yang diambil secara random untuk melihat pengaruh reallotment activities terhadap hasil belajar atau kemampuan matematis.

\section{DAFTAR RUJUKAN}

Balingga, E., Prahmana, R. C. I., \& Murniati, N. (2016). Analisis kemampuan reversibilitas siswa MTs kelas VII dalam menyusun persamaan linier. JRPM (Jurnal Review Pembelajaran Matematika), 1(2), 117-131.

Darmawati, D., Irawan, E. B., \& Chandra, T. D. (2017). Kesalahan siswa SMP dalam menyelesaikan soal bangun datar segiempat berdasarkan teori Nolting. In Prosiding Seminar Nasional Mahasiswa Kerjasama Direktorat Jenderal Guru dan Tenaga Kependidikan Kemendikbud 2016. 
Ismail, Z., \& Rahman, S. N. A. (2017). Learning 2-dimensional and 3-dimensional geometry with geogebra: Which would students do better? International Journal on Emerging Mathematics Education, 1(2), 121-134.

Khoiri, M. (2014). Pemahaman siswa pada konsep segiempat berdasarkan teori van Hiele. Prosiding Seminar Nasional Matematika. Malang: Universitas Jember, (pp. 262267).

Khotimah, H. (2013). Meningkatkan hasil belajar geometri dengan teori van Hiele. Seminar Nasional Matematika dan Pendidikan Matematika. Yogyakarta: Universitas Negeri Yogyakarta, (pp. 9-16).

Kolnel, R. P. D., Prahmana, R. C. I., \& Arifin, S. (2015). Pengaruh pembelajaran matematika gasing pada materi geometri terhadap hasil belajar siswa kelas VII sekolah menengah pertama. Jurnal Numeracy, 2(1), 70-76.

Kurniati, D. (2010). Analisis kesalahan siswa kelas VII SMP Negeri 2 Puger dalam menyelesaikan soal yang berkaitan dengan persegi panjang dan persegi. Prosiding Seminar Pendidikan Matematika.Malang: Universitas Negeri Malang, (pp. 153166).

Muhtadi, D., Sukirwan, Warsito, \& Prahmana, R. C. I. (2017). Sundanese ethnomathematics: Mathematical activities in estimating, measuring, and making patterns. Journal on Mathematics Education, 8(2), 185-198.

Mumu, J., Prahmana, R. C. I., \& Tanujaya, B. (2017). Construction and reconstruction concept in mathematics instruction. Journal of Physics: Conference Series, 943(1), 012011.

Novita, R., Prahmana, R. C. I., Fajri, N., \& Putra, M. (2018). Penyebab kesulitan belajar geometri dimensi tiga. Jurnal Riset Pendidikan Matematika, 5(1), 18-29.

Nugraheni, E. M. \& Sugiman. (2013). Pendekatan PMRI terhadap aktivitas dan pemahaman konsep matematika siswa SMP. Pythagoras, 8(1), 101-108.

Olivia, C., Pinta, D., \& Meiliasari. (2013). Mengembangkan pemahaman relasional siswa mengenai luas bangun datar segiempat dengan pendekatan PMRI. Seminar Nasional Matematika dan Pendidikan Matematika.Yogyakarta: Universitas Negeri Yogyakarta, (pp. 125-132). 
Prahmana, R. C. I. (2012). Pendesainan pembelajaran operasi bilangan menggunakan permainan tradisional tepuk bergambar untuk siswa kelas III Sekolah Dasar (SD). Unpublished Thesis. Palembang: Magister Pendidikan Matematika Universitas Sriwijaya.

Prahmana, R. C. I. (2015). Penelitian Pendidikan Matematika: Pembelajaran Berbasis Riset. Yogyakarta: CV. Graha Ilmu (Matematika).

Prahmana, R. C. I., Zulkardi, \& Hartono, Y. (2012). Learning multiplication using Indonesian traditional game in third grade. Journal on Mathematics Education, 3(2), 115-132.

Revina, S., \& Leung, F. K. S. (2018). Educational borrowing and mathematics curriculum: Realistic mathematics education in the Dutch and Indonesian primary curriculum. International Journal on Emerging Mathematics Education, 2(1), 116.

Rofii, A., Sunardi, S., \& Irvan, M. (2018). Characteristics of students' metacognition process at informal deduction thinking level in geometry problems. International Journal on Emerging Mathematics Education, 2(1), 89-104.

Ryandi, R. B., Somakim, S., \& Susanti, E. (2018). Learning combinations through "Handshake". International Journal on Emerging Mathematics Education, 2(1), 105-118.

Yunianto, W. (2014). Supporting 7th grade student's understanding of the area measurement of quadrilaterals and triangles through reallotment activities. Unpublished Thesis. Palembang: Magister Pendidikan Matematika Universitas Sriwijaya dan Utrecht: Utrecht University. 